ОСОБЛИВОСТІ РОЗВИТКУ

СВІТОВОГО ГОСПОДАРСТВА ТА МЕВ

УДК $336.58: 378$

\title{
ENDOWMENT FUND ESTABLISHMENT AS A RESPOND TO THE CHALLENGES OF THE EPOCH
}

\section{СТВОРЕННЯ ЕНДАУМЕНТ-ФОНДІВ ЯК ВІДПОВІДЬ НА ВИКЛИКИ СУЧАСНОЇ ЕПОХИ}

\section{СОЗДАНИЕ ЭНДАУМЕНТ-ФОНДОВ КАК ОТВЕТ НА ВЫЗОВЫ СОВРЕМЕННОЙ ЭПОХИ}

\author{
Golovko A.
}

$\mathrm{PhD}$, research worker of Institute of international relations Taras Shevchenko National University of Kyiv.

Головко А. Я.

Кандидат економічних наук, науковий співробітник Інституту міжнародних відносин Київського національного університету імені Тараса Шевченка.

\section{Головко А. Я.}

Кандидат экономических наук, научный сотрудник Института международных отношений Киевского национального университета имени Тараса Шевченко.

Abstract. Insufficient funding forces universities to search for innovative models of additional financing. The multichannel financing of education and science, based on combination of budgetary and extrabudgetary funding, becomes dominant position. The special place among extrabudgetary funding occupies the establishment of specific fund for national, meaningful projects financing (endowment). Endowment funds activity is supported by the first point of Bologna declaration, that proclaims higher education institutions the establishments that bear all responsibility for the future of the state, and, consequently, such, that must be apt neither to political, nor economic, nor social, nor other influences. World practice of endowments, the legislative framework of endowments, universities advantages due to endowment establishment, factors that confirm actuality of creation of such funds are analyzed in the article.

Key words: endowment fund, extrabudgetary funding, higher education, specific capital.

Анотація. Недостатність фінансування спонукає вищі навчальні заклади до пошуку інноваційних моделей додаткового фрінансування. Домінуючою позицією стає багатоканальне фінансування освіти та науки, яке трунтується на поєднанні бюджетних та позабюджетних джерел. Особливе місие серед позабюджетних джерел фінансування займає створення цільового фонду для фінансування загальнонаціональних, значущих проектів (ендаументу). Діяльність ендаумент-фондів підкріплює перший пункт Болонської декларації, щзо проголошує ВИШі закладами, які несуть на собі все навантаження по майбутньому держави, а отже такими, щуо не мають бути схильні ні політичним, ні 
економічним, ні сочіальним, ніяким іншим впливам. У статті розглянута світова практика функціонування ендаумент-фондів, проаналізовано законодавче забезпечення ендаументів, переваги, які отримуються вищиим навчальними закладами за рахунок їх створення, фактори, щуо підтверджують актуальність створення таких фондів.

Ключові слова: ендаумент-фонд, позабюджетне фінансування, вища освіта, иільовий капітал.

Аннотация. Недостаточность финансирования побуждает высшие учебные заведения к поиску инновачионных моделей дополнительного финансирования. Доминирующей позицией становится многоканальное финансирование образования и науки, которое основывается на сочетании бюджетных и внебюджетных источников. Особенное место среди внебюджетных источников финансирования занимает создание целевого фонда для финансирования общенациональных, значимых проектов (эндаумента). Деятельность эндаумент-фондов подкрепляет первый пункт Болонской декларации, которая провозглашает ВУЗы заведениями, несущими на себе всю нагрузку по будущееу государства, а, следовательно, такими, которые не должны быть склонны ни к политическим, ни экономическим, ни сочиильным, никаким другим влияниям. В статье рассмотрена мировая практика функиионирования эндаумент-фондов, проанализировано законодательное обеспечение эндаументов, преимущества, которые получаются высшими учебными заведениями за счет их создания, факторы, подтверждающие актуальности создания таких фондов.

Ключевые слова: эндаумент-фонд, внебюджетное финансирование, высшее образование, иелевой капитал.

Introduction. Home educational establishments are forced to secure the alternative sources of financing, search for grants, use fundraising technologies to provide sustainable development on principles of innovations introduction and leading educational practices. Endowment fund represents the powerful instrument for providing the autonomy and effective operational activity of universities, financing of innovative study programs and scientific researches. An endowment is a financial asset, in the form of a donation made to a non-profit group, institution or individual consisting of investment funds or other property that may or may not have a stated purpose at the bequest of the donor. Most endowments are designed to keep the principal amount intact while using the investment income from dividends for charitable efforts [5]. Their funding comes from a combination of legacies, gifts and investment returns.

Review of literature. The problem of educational endowments establishment is investigated by C. Calhoun, B. Johnston, H. Hansmann, H. L. Lee, J. Lerner, D. Newman, A. Schoar, E. C. Schumacher, J. Wang; in Russian Federation - by T. Abankina, V. Benevolensky, S. Guriev, A, Kostin, E. Knyazev, O. Kuzyna, Y. Mirkin, V. Yakimets. At the same time, Ukrainian scientific researchers are quite insufficient at this field.

The purpose of the article is the revision of structure and logic of extrabudgetary funding of educational and research activity of Ukrainian higher educational establishments due to improvement of organizational and economic terms of special purpose funds establishment in Ukraine based on analysis and generalization of foreign experience.

Key research findings. Positive world experience in university's endowment funds establishment convincingly showed high role of endowments as one of strategic mechanisms on financing activity \& development of higher education system. It stipulates the relevance of determination of principles and prospects of their establishment in Ukraine. 
Key benefits of an endowment fund include also following:

- Creates an ongoing source of income. Because a permanent endowment is an invested pool of money that provides a reliable source of income in perpetuity, the organization can count on annual distributions for its charitable work. Funds may be designated for endowment by the donor or by the board of directors. With appropriate investment and spending policies, the endowment's purchasing power will be preserved. Thus, a fund that generates income to operate a reading recovery program for elementary students today can be designed to produce income to run the same program 20 years from now and beyond. The endowment also grows over time with additional gifts from multiple donors;

- Enhances stability and prestige. A well-managed endowment sends a message of planned long-term stability, fiscal responsibility, and financial viability. It enhances the organization's prestige and credibility;

- Relieves pressure on the annual fund. Annual fund goals tend to rise right along with the cost of providing services and operating the organization, but the ability of the annual fund to meet increasing demand is not limitless. An endowment can provide annual support for the organization's operating budget;

- Allows expansion. Expansion can be funded with distributions from endowment funds used for scholarships, faculty chairs, staff positions, lecture series, research, facility maintenance, equipment and supplies, and for any other purpose designated by the donor or by the board of directors;

- Provides independence. Endowment contributions designated for specific purposes can provide a measure of independence from economic, governmental, and political forces;

- Offers flexibility for management. Endowments offer options to meet new challenges by providing greater financial flexibility and self-sustaining income streams. Endowments can augment uncertain income sources, broaden the overall revenue mix, improve the income statement, and provide leverage for bond-rating capacity and loans for new facilities;

- Is an attractive method to reward major donors;

- Is managed by professionals.

Endowments have their origin in Great Britain. The development and confession it got in the USA. From 1972 practically all states that have charitable contribution rules used the law of UMIFA (Uniform Management of Institutional Funds Act) for co-ordination of endowment funds activity. UMIFA was a pioneering statute, providing uniform and fundamental rules for the investment of funds held by charitable institutions and the expenditure of funds donated as "endowments" to those institutions [2]. Those rules supported two general principles: 1) that assets would be invested prudently in diversified investments that sought growth as well as income, and 2) that appreciation of assets could prudently be spent for the purposes of any endowment fund held by a charitable institution.

At its annual meeting in July 2006, the National Conference of Commissioners on Uniform State Laws (NCCUSL) approved the Uniform Prudent Management of Institutional Funds Act (UPMIFA) and recommended it for enactment by the legislatures of the various states. UPMIFA was designed to replace the UMIFA [3]. UMIFA initiated the era of modern portfolio management for charitable institutions. UPMIFA provides the standards and guidelines that subsequent experience tells us are the most appropriate for the purpose. It reflects and incorporates the 35 years of experience that has accumulated under the original UMIFA. Rather than changing institutional investment or expenditure practices, it brings them up to date and unifies them across a broad range of charitable funds. 
One may denote the set of factors that confirm actuality of establishment of such funds on today, which are as follows:

- the fact of public disappointment at the actions taken by the government is observed. At the same time, there is a growing confidence in the business enterprises, funds, non-governmental organizations;

- the attitude toward charity as to professional employment has spread ahead and became a "social norm";

- in comparison to the state the endowment fund of higher educational establishment express greater motivation to implementation of own projects for competition reasons;

- the analysis of world experience shows a high index of endowment funds activity efficiency;

- there is a post-crisis business activity activation that requires professional personnel with high skills and modern education;

- the direct connection of endowment fund with university increases efficiency of fund's actions through understanding of urgent university necessities and possibility of immediate actions. In other words, university gets freedom in decision making.

Today endowments represent the powerful instrument of financing of innovative study programs and scientific researches all over the world. The largest endowment funds in the USA are Harvard, Yale, Princeton and Stanford universities' funds. They incorporate billion of U.S. dollars that allow spending up to $\$ 1$ billion annually on their current expenses. Generally, all universities with the biggest endowment funds are in the USA [6]. The largest endowments in Europe belong to universities of Cambridge (Great Britain), Oxford (Great Britain), Zurich (Switzerland), Copenhagen (Denmark), and Utrecht (Netherlands) [7]. In these and other leading foreign universities the funds got from endowments' forms up to $45 \%$ of annual budget.

In 80 universities of the world the volume of endowments' capital exceeds $\$ 1$ billion. Frequently it is not even one fund, but is made up of system of funds, each of that has its own goal. For example, the two largest categories of Harvard endowment funds cover faculty salaries, including professorships, and financial aid for undergrads, graduate fellowships, and student life and activities. At the same time, Harvard also has endowments that support academic programs, libraries, art museums, facilities, and a wide variety of other activities. Total investments in USA and Canada endowment funds are approximately equal to GDP of Ukraine. Such worldwide projects as Google and Facebook were at first supported exactly by endowment funds of Stanford and Harvard universities. Well-known The Nobel Foundation is also an endowment, established by Alfred Nobel. In his will of November 27, 1895 signed in Paris, Alfred Nobel specified that the bulk of his fortune should be divided into five parts and to be used for Prizes in Physics, Chemistry, Physiology or Medicine, Literature and Peace to "those who, during the preceding year, shall have conferred the greatest benefit to mankind"[10].

Practice of creation of universities' endowment funds establishments appeared to be effective on territory of post-soviet countries as well. Due to report of Russian Donors Forum Partnership, there were more than 100 special purpose capital funds registered in Russia on 2015. Slightly more than half of registered funds have already formed the endowment, other are carrying out campaigns for attracting donations. The general amount of capital invested in funds is over 25 billion of rubles. Most of endowments were created for education and scientific organizations support (71\%) [4].

Today the largest endowments among universities in Russian Federation belong to the Skolkovo Institute of Science and Technology (Skoltech) [11], Moscow State Institute of International Relations [9], Saint Petersburg State University [12], European University at Saint Petersburg [8]. 
All mentioned funds were established in order to accumulate long-term capital and spend the investment income on the development of educational programs, financing of research, improvement of infrastructure, support library funds, etc. Most investors think in terms of two dimensional portfolios comprised of stocks and bonds. Endowments expand their portfolio to include a third dimension by using alternative investments. The primary benefit of using alternative investments in a portfolio is to augment the risk-adjusted returns provided by a two dimensional stock-bond portfolio. Through this approach endowments increase their capital. An important moment is that endowment funds activity is supported by the first point of Bologna Declaration, that proclaims Institutions of higher education the establishments that bear all responsibility for the future of the state, and, consequently, such, that must be apt neither to political, nor economic, nor social, nor other influences. It also comports with the second point of Declaration that proclaims the necessity of science and education unity. Except that, endowment is the stimulus of academically improvement as well as university's reputation enhancement, because due to world experience, donors of such funds are graduating students in their majority. Accordingly, innovation can become good pre-condition for the increased competition of higher educational establishments. Quality and relevance of education, support of traditions and other factors could influence not only major donors choice of that or another endowment, but graduating students decision to donate as well.

The first steps toward endowment fund establishment in Ukraine were already taken by two national universities, Institute of International Relations of Taras Shevchenko National University of Kyiv (in 2013) and The Banking University of the National Bank of Ukraine (in 2014). Although, minding the absence of both the necessary legal framework and imposition of endowment fund status by legislation they de jure should be considered as charitable institution. However, The Law of Ukraine «On higher education», that entered into force on September, 6, 2014, provides for qualitatively new principles of functioning and development of the higher education system in Ukraine, including autonomy expansion of higher educational establishments in different spheres. One of novelties calls for universities' financial independence that should be achieved through: the right to conduct financial and economic activity, that does not conflict with a legislation and charter; the right to dispose of own income from paid services provision; the right to dispose of income from grants and charitable assistance; to open own current and deposit accounts; to establish sustainable funds (endowments) [1].

Conclusions. Considering the absence of prospects of improving state financing, partial university financial autonomy, namely, endowment fund establishment should be considered as effective step.

Development of necessary legal framework for full existence and endowment funds' defense, carrying out complex propagandist campaign aimed for explanation and distribution of core idea of endowment funds will ensure positive prospects of their development that, in a turn, will provide:

- development and introduction of new educational technologies and active methods of studies;

- increased universities' integration with branch scientific and project institutions, large scientific and production associations;

- participation of the Ukrainian scientists in the intergovernmental programs implementation;

- possibility of intellectual labor results implementation on the national territory;

- increase of investment attractiveness of educational sphere on the basis of the effective and mutually advantageous cooperation with business society, of civil society institutions, public and local self-government authorities. 


\section{References}

1. Закон України «Про вищу освіту» [The Law of Ukraine «On higher education»], $<\mathrm{http}$ //search.ligazakon.ua/1_doc2.nsf/link1/T141556.html $>$

2. The National Conference of Commissioners on Uniform State Laws, Uniform Law Commission, $<\mathrm{http}: / /$ www.uniformlaws.org $>$

3. Gary S. UMIFA Becomes UPMIFA, <http://uniformlaws.org/Shared/Docs/UMIFA Becomes UPMIFA.pdf $>$

4. Investopedia Business Dictionary, <http://www.investopedia.com/terms/e/endowmentfund $>$

5. Доклад о состоянии и развитии фондов в России [Report about the state and development of funds in Russia], < http://www.donorsforum.ru/projects/annual-report/doklad-2015goda $>$

6. 10 Universities With the Largest Endowments, <http://www.usnews.com/education/bestcolleges/the-short-list-college/articles/2015/10/06/10-universities-with-the-largest-endowments>

7. List of European universities by endowment, $<$ https://en.wikipedia.org/wiki/List_of_European_universities_by_endowment>

8. The official web-site of European University at Saint Petersburg $<$ https://eu.spb.ru/en/ $>$

9. The official web-site of Moscow State Institute of International Relations, $<$ http://english.mgimo.ru/>

10. The official web-site of the Nobel Prize, $<$ https://www.nobelprize.org/alfred_nobel/>

11. The official web-site of the Skolkovo Institute of Science and Technology, $<$ http://www. skoltech.ru/en/>

12. The official web-site of Saint Petersburg State University, $<$ http://english.spbu.ru $>$ 